\title{
Empirical and theoretical challenges in aboveground-belowground ecology
}

\author{
Wim H. van der Putten · R. D. Bardgett · P. C. de Ruiter · W. H. G. Hol • K. M. Meyer • \\ T. M. Bezemer $\cdot$ M. A. Bradford $\cdot$ S. Christensen $\cdot$ M. B. Eppinga $\cdot$ T. Fukami $\cdot$ \\ L. Hemerik $\cdot$ J. Molofsky $\cdot$ M. Schädler $\cdot$ C. Scherber $\cdot$ S. Y. Strauss $\cdot$ M. Vos $\cdot$ D. A. Wardle
}

Received: 16 December 2008 / Accepted: 12 March 2009 / Published online: 3 May 2009

(C) The Author(s) 2009. This article is published with open access at Springerlink.com

\begin{abstract}
A growing body of evidence shows that aboveground and belowground communities and processes are intrinsically linked, and that feedbacks between these subsystems have important implications for community structure and ecosystem functioning. Almost all studies on this topic have been carried out from an empirical perspective and in specific ecological settings or contexts. Belowground interactions operate at different spatial and temporal scales. Due to the relatively low mobility and high survival
\end{abstract}

Communicated by Roland Brandl.

W. H. van der Putten $(\varangle)$ · W. H. G. Hol · K. M. Meyer •

T. M. Bezemer

Department of Multitrophic Interactions,

Centre for Terrestrial Ecology,

Netherlands Institute of Ecology NIOO-KNAW,

Boterhoeksestraat 48, 6666 GA Heteren, The Netherlands

e-mail:w.vanderputten@nioo.knaw.nl

W. H. van der Putten - T. M. Bezemer

Laboratory of Nematology, Wageningen University,

P.O. Box 8123, 6700 ES Wageningen, The Netherlands

R. D. Bardgett

Lancaster Environment Centre, Soil and Ecosystem Ecology,

University of Lancaster, Lancaster LA1 4YQ, UK

P. C. de Ruiter

Soil Centre, Wageningen University,

Droevendaalsesteeg 3, 6708 PB Wageningen,

The Netherlands

K. M. Meyer

Faculty of Forest Sciences, Ecosystem Modelling,

Göttingen University, Büsgenweg 4,

37077 Göttingen, Germany

M. A. Bradford

School of Forestry and Environmental Studies,

Yale University, New Haven, CT 06511, USA of organisms in the soil, plants have longer lasting legacy effects belowground than aboveground. Our current challenge is to understand how aboveground-belowground biotic interactions operate across spatial and temporal scales, and how they depend on, as well as influence, the abiotic environment. Because empirical capacities are too limited to explore all possible combinations of interactions and environmental settings, we explore where and how they can be supported by theoretical approaches to

S. Christensen

Department of Terrestrial Ecology, University of Copenhagen,

Oster Farimagsgade 2D, 1353 Copenhagen K, Denmark

M. B. Eppinga

Department of Environmental Science, Copernicus Institute,

University of Utrecht, POB 80115, 3508 TC Utrecht,

The Netherlands

T. Fukami

Department of Biology, Stanford University,

Stanford, CA 94305, USA

L. Hemerik

Biometris, Department of Mathematical and Statistical Methods, Wageningen University, POB 100, 6700 AC Wageningen,

The Netherlands

J. Molofsky

Department of Plant Biology,

University of Vermont, Burlington, VT 05405, USA

M. Schädler

Department of Animal Ecology, Faculty of Biology,

University of Marburg, Karl von Frisch Str 8,

35032 Marburg, Germany 
develop testable predictions and to generalise empirical results. We review four key areas where a combined aboveground-belowground approach offers perspectives for enhancing ecological understanding, namely succession, agro-ecosystems, biological invasions and global change impacts on ecosystems. In plant succession, differences in scales between aboveground and belowground biota, as well as between species interactions and ecosystem processes, have important implications for the rate and direction of community change. Aboveground as well as belowground interactions either enhance or reduce rates of plant species replacement. Moreover, the outcomes of the interactions depend on abiotic conditions and plant life history characteristics, which may vary with successional position. We exemplify where translation of the current conceptual succession models into more predictive models can help targeting empirical studies and generalising their results. Then, we discuss how understanding succession may help to enhance managing arable crops, grasslands and invasive plants, as well as provide insights into the effects of global change on community re-organisation and ecosystem processes.

Keywords Succession - Sustainable crop protection . Invasion · Global change · Temporal and spatial models

\section{Introduction}

Terrestrial ecosystems consist of aboveground and belowground subsystems that contain a vast number of species interacting at various spatial and temporal scales. In recent years, a growing body of empirical studies has shown that aboveground-belowground interactions have important consequences for community organisation and ecosystem processes. Several reviews have already analysed specific

C. Scherber

Department of Agroecology, Göttingen University,

Waldweg 26, 37073 Göttingen, Germany

\section{S. Y. Strauss}

Section of Evolution and Ecology,

University of California Davis, Davis, CA 95616, USA

\section{Vos}

Department of Ecosystem Studies,

Centre for Estuarine and Marine Ecology,

Netherlands Institute of Ecology NIOO-KNAW,

Korringaweg 7, 4401 NT Yerseke, The Netherlands

D. A. Wardle

Department of Forest Ecology and Management,

Swedish University Agricultural Science,

90183 Umeå, Sweden types of aboveground-belowground interactions, such as between belowground decomposers and aboveground invertebrate (Scheu 2001; Bonkowski 2004), and vertebrate herbivores (Bardgett and Wardle 2003), aboveground and belowground insect herbivores (Masters et al. 1993), mycorrhizal fungi and insects (Gange and Brown 2002), and aboveground-belowground multitrophic interactions (Van der Putten et al. 2001). However, the complexity of possible interactions between aboveground and belowground species, their interactions with the abiotic environment and their variations in spatial and temporal scales at which they operate, is enormous (Wardle 2002).

The previous reviews have clearly set the concepts; however, theory that predicts the outcome and consequences of aboveground-belowground interactions is still in its infancy. The concept of aboveground-belowground ecology assumes that plants, aboveground biota and soil biota are all part of one system, in which aboveground and belowground individuals, populations and communities influence each other. Abiotic environmental conditions influence the local biotic interactions, which in turn change the abiotic conditions, creating aboveground-belowground feedback effects that work out as changes in ecosystems. Including belowground interactions is not only a matter of enhancing the number of interactions, because they also take place at different spatial and temporal scales. For example, vertebrate herbivores explore areas exceeding the size of 1 ha within a day, whereas most soil organisms do not explore more than $1 \mathrm{~m}^{2}$ in their life time. Moreover, the legacy effect of plant roots on the soil, due to the poor dispersal capacity and long survival of many soil organisms, have substantial effects on the outcome of aboveground interactions.

There are generally two approaches taken in studies on aboveground-belowground interactions. The first is the primary producer approach, which considers how roots and shoots, aboveground and belowground herbivores, pathogens and symbionts, their predators and the predators of the predators interact. The interactions can be direct, or indirect, via changes in aboveground and belowground primary plant compounds (Masters and Brown 1997) and via secondary, defensive, compounds (Van der Putten et al. 2001). The second is the detritus approach which considers how dead organic material (detritus), microbial decomposers, detritivores, microbivorous organisms and predators interact (Wardle 2002). The decomposition of the detritus, which mainly takes place belowground, has major consequences for plant nutrition, and feeds back to plant interactions with herbivores, pathogens, symbionts and their natural enemies both aboveground and belowground. Various reviews have proposed mixtures of these two approaches (Scheu 2001; Wardle et al. 2004), often focusing on subsets of all possible interactions, such as between 
aboveground herbivory and soil decomposer organisms (Bardgett et al. 1998; Bardgett and Wardle 2003).

To date, almost all aboveground-belowground interaction studies have been carried out from an empirical perspective. The parameter space that has been explored is still limited, because experimental testing of all possible interactions would require many detailed case-specific studies. Modelling approaches, which could identify essential interactions on which empirical efforts can then be targeted, are still in their infancy (Schröter et al. 2004; Bennett and Bever 2007). The aim of our review is to identify opportunities for combining future empirical studies with modelling approaches that could enhance our conceptual understanding and predictive capacity. These approaches may range from conceptual and graphical models to more predictive models including process- and individual-based models with and without explicit consideration of spatial relationships (Table 1). These modelling approaches offer a great potential for expansion of their current contribution to aboveground-belowground ecology in combination with empirical data, for example with respect to their ability to capture the complexity and scale-dependence of aboveground-belowground interactions (Table 1). Such a combined approach has been successful in other areas, for example in understanding how bottom-up and top-down interactions in food webs may vary both in direction and in strength (Moore et al. 2003).

To explore how aboveground-belowground interactions may depend on plant species traits and environmental conditions, we focus initially on natural succession, where traits and environmental conditions vary both within and between stages of ecosystem development. Then, we consider three other areas where, in our opinion, considerable progress could be made by adopting an abovegroundbelowground interaction approach: crop protection in agriculture, biological invasions, and global climate change.

\section{Aboveground-belowground interactions and succession}

Drivers of primary and secondary succession

Succession is the change in composition of natural vegetation over time, and the processes of colonisation, facilitation, competition, senescence and replacement determine the rate and direction of succession (Walker and Chapin 1987; Walker and del Moral 2003). It is well established that these processes are strongly regulated by abiotic environmental conditions, such as soil disturbance, moisture availability, $\mathrm{pH}$ and nutrient availability. However, the role of biotic interactions in plant succession, especially how biotic interactions between plants, aboveground and belowground organisms work out into plant species replacement, is less well understood. For instance, while succession has been studied for more than a century, major questions remain about the role of facilitation and inhibition processes in vegetation community dynamics (Brooker et al. 2007) and the predictability of changes in the rate and direction of succession (Connell and Slatyer 1977; Walker and del Moral 2003). Even less is known about the combined contribution of aboveground and belowground biotic interactions to succession, the interaction between primary producers, herbivores, decomposer organisms and predators, and how the outcomes of these interactions are altered by changes in the abiotic environment as succession proceeds.

Primary succession starts on bare soil with sparse vegetation cover of ruderal species with fast growth-rate and high investment in reproduction for dispersal (Grime 2001; Walker and del Moral 2003). Initially, soil food webs are very simple, being composed of simple heterotrophic microbial communities (Bardgett et al. 2007) and photosynthetic and nitrogen-fixing bacteria (Schmidt et al. 2008), developing towards more complex, fungal-based food webs over time (Bardgett and Walker 2004; Neutel et al. 2007). In contrast, secondary succession usually starts with relatively high soil organic matter content and nutrient availability, a well-developed seed bank and soil food web, and fast-growing, weedy plant species that are more limited by light than by nutrients (Tilman 1988).

Traditionally, when explaining drivers of succession the focus has been on abiotic environmental factors. At large spatial and long temporal scales, abiotic conditions such as changes in $\mathrm{pH}$, soil organic matter and nutrient availability, and shifts in light availability, generally correlate well with gradients in vegetation composition (e.g. Olff et al. (1994)). However, at shorter temporal scales of months to decades, successional patterns may be better explained by interactions between plants, aboveground and belowground biota (Veblen 2008).

In many cases where managed and natural terrestrial ecosystems are exposed to vertebrate herbivores, such as voles, rabbits, avian and large mammal grazers, grazing retards vegetation succession by selectively suppressing late successional plant species (Van der Wal et al. 2000; Bardgett and Wardle 2003). Otherwise, grazers may promote dominant plant species that benefit from herbivory, for example through compensatory growth (Augustine and McNaughton 1998), or accelerate succession by selective feeding on earlier successional, palatable and nutrient-rich plant species (Cates and Orians 1975; Pastor et al. 1993; Ritchie et al. 1998). The influences of herbivorous insects on vegetation succession vary with successional type, successional stage and between the aboveground and belowground community interactions. For example, aboveground insect herbivory slowed down primary succession and 
Table 1 Overview of model types that have been used to model aboveground-belowground interactions, and the possible contribution of these types of models to empirical studies on aboveground-belowground ecology

\begin{tabular}{|c|c|c|}
\hline $\begin{array}{l}\text { Aboveground-belowground } \\
\text { model type }\end{array}$ & Brief description of model structure & $\begin{array}{l}\text { (Potential) Contribution to empirical } \\
\text { aboveground-belowground (AG-BG) ecology }\end{array}$ \\
\hline Conceptual models ${ }^{\mathrm{a}}$ & $\begin{array}{l}\text { Often displayed as a schematic diagram showing } \\
\text { the processes and relationships that connect } \\
\text { the individual components of a system }\end{array}$ & $\begin{array}{l}\text { Provide the appropriate level of detail } \\
\text { that is needed in empirical studies that } \\
\text { address a related research question }\end{array}$ \\
\hline Graphical models ${ }^{\mathrm{b}, \mathrm{c}}$ & $\begin{array}{l}\text { One or more graphs indicating how a process rate or } \\
\text { the strength of a relationship changes over } \\
\text { a range of system conditions }\end{array}$ & $\begin{array}{l}\text { Identification of key relationships } \\
\text { that induce positive and negative } \\
\text { feedbacks within an AG-BG system }\end{array}$ \\
\hline Process-based models ${ }^{\mathrm{d}, \mathrm{e}, \mathrm{f}}$ & $\begin{array}{l}\text { For each individual component of the system } \\
\text { (state variable), the processes and relationships } \\
\text { that affect the component are mathematically defined. } \\
\text { This yields for each state variable an equation } \\
\text { (differential equation) that describes how this } \\
\text { state variable changes over time }\end{array}$ & $\begin{array}{l}\text { Provide hypotheses how an AG-BG } \\
\text { system responds to changes } \\
\text { in environmental conditions } \\
\text { Provide hypotheses how an AG-BG } \\
\text { system responds to changes in the } \\
\text { community composition } \\
\text { (i.e. removal or introduction of species) } \\
\text { Provide a means to assess emergent } \\
\text { properties of the ecosystem level that } \\
\text { are difficult to measure directly } \\
\text { (e.g. system stability that arises through } \\
\text { non-random patterning of interaction strengths) }\end{array}$ \\
\hline $\begin{array}{l}\text { Spatially implicit } \\
\text { process-based models }^{\mathrm{g}, \mathrm{h}}\end{array}$ & $\begin{array}{l}\text { A type of process-based models that distinguishes } \\
\text { global state variables affecting all model components } \\
\text { from local or regional state variables that only } \\
\text { affect a smaller-scale subsystem }\end{array}$ & $\begin{array}{l}\text { Similar hypotheses-formulating function } \\
\text { as for other process-based models. } \\
\text { The implicit consideration of space, however, } \\
\text { may lead to predictions that differ from } \\
\text { non-spatial process-based models, } \\
\text { e.g. predictions of resource limitation } \\
\text { and coexistence }\end{array}$ \\
\hline $\begin{array}{l}\text { Spatially explicit } \\
\quad \text { reaction-diffusion models }{ }^{i}\end{array}$ & $\begin{array}{l}\text { The model system is divided into an arbitrary number } \\
\text { of spatial units (grid cells). A process-based model } \\
\text { is defined for each grid cell. Through spatial processes, } \\
\text { there can be exchange of matter, species and energy } \\
\text { between grid cells. A grid cell, however, is only a means } \\
\text { to make the system discrete, and has no ecological meaning }\end{array}$ & $\begin{array}{l}\text { Enables predictions of spread and movement } \\
\text { of species through landscapes. Importantly, } \\
\text { the enormous variation of spatial scales } \\
\text { of processes in AG-BG systems can } \\
\text { be accounted for in the predictions }\end{array}$ \\
\hline $\begin{array}{l}\text { Spatially explicit cellular } \\
\quad \text { automata models }{ }^{\mathrm{j}}\end{array}$ & $\begin{array}{l}\text { Similar to reaction-diffusion models, except that a grid cell } \\
\text { in a cellular automaton model does have an ecological } \\
\text { meaning (e.g. a spot that can be colonised by one plant). } \\
\text { Therefore, the model can also include rules that describe } \\
\text { how the state of a grid cell depends on the state } \\
\text { of neighbouring grid cells }\end{array}$ & $\begin{array}{l}\text { Similar to reaction-diffusion models. Through } \\
\text { the explicit consideration of the scale } \\
\text { of individuals, this type of models may be } \\
\text { particularly useful to explore the process of } \\
\text { introduction and establishment of new species } \\
\text { in an AG-BG community (e.g. succession, } \\
\text { invasion or outbreak of a disease) }\end{array}$ \\
\hline Individual-based models ${ }^{\mathrm{k}}$ & $\begin{array}{l}\text { Equation- or rule-based models in which population- } \\
\text { or community-level patterns emerge from interactions } \\
\text { and adaptive behaviour of individual organisms whose } \\
\text { individual properties such as body size affect the } \\
\text { modelled processes }\end{array}$ & $\begin{array}{l}\text { Similar to process-based models, with the } \\
\text { additional benefit of capturing the potentially } \\
\text { complex AG-BG interactions at the } \\
\text { biologically realistic level of individual } \\
\text { organisms }\end{array}$ \\
\hline
\end{tabular}

Examples of model studies that have been applied to aboveground-belowground research questions:

a Schröter et al. (2004)

b Rietkerk and Van de Koppel (1997)

c Holmgren et al. (1997)

d De Ruiter et al. (1995)

e Bever (2003)

${ }^{\mathrm{f}}$ Moore et al. (2004)

g Huston and DeAngelis (1994)

h Loreau (1998)

i Levine et al. (2006)

j Bonanomi et al. (2005)

${ }^{\mathrm{k}}$ Meyer et al. (2009) 
ecosystem development on post-eruption Mount St. Helens by selectively suppressing lupins (Fagan and Bishop 2000), and aboveground herbivorous beetles delayed primary succession on sand dunes by reducing the performance of woody species (Bach 1994).

While little is known about the role of belowground insect herbivory in primary succession, its role in secondary succession is better known. In pioneering succession experiments in the southern UK, where Brown and Gange (1989, 1992, 1993) used selective insecticides to exclude both aboveground and belowground insects from early and later secondary succession stage grasslands. Their results suggest that aboveground insect herbivory slows down secondary succession by preventing perennial grass development, whereas root-feeding insects enhance early secondary succession by reducing early succession annual forbs (Brown and Gange 1992). A field exclusion experiment in Germany also revealed a driving role of belowground insects, whereas excluding aboveground insects did not affect plant species replacement (Schädler et al. 2004). A mesocosm addition experiment in The Netherlands showed that belowground nematodes, wireworms and microarthropods enhanced the replacement of early by later secondary succession plant species (De Deyn et al. 2003).

Microbial pathogens and endophytic fungal symbionts may enhance or slow down both primary and secondary succession (Van der Putten et al. 1993; Clay and Holah 1999). Although mycorrhizal communities vary along successional trajectories (Johnson et al. 1991), few studies have actually quantified the importance of these symbiotic associations (Hart et al. 2001). However, soil feedback studies along a secondary chronosequence suggested that the proportional roles of pathogens and arbuscular mycorrhizal fungi in net plant-soil feedback effects could change over the course of succession (Kardol et al. 2006). Although plant-microbe interactions are rarely considered from the perspective of aboveground-belowground interactions, they have clear potential to indirectly influence interactions between plant species, as well as between plants, herbivores, pollinators, or detritivores (Hines et al. 2006).

\section{Modelling succession}

As far as we know, there is no quantitative model yet operative that includes aboveground-belowground interactions between plants and higher trophic level organisms in primary or secondary succession. There are some conceptual models that place the role of biotic interactions as drivers of succession in a spatial or temporal context, but most of these models focus on one subsystem, either aboveground or belowground, at a time. For example, a conceptual model suggests that aboveground herbivorous insects retard succession from earlier stages to intermediate stages dominated by grasses, shrubs and pioneer trees, but that they enhance succession from intermediate stages to permanent trees (Davidson 1993). This model assumes that intermediate stages of succession are subject to high herbivore pressure, but ignores the very early stages of succession.

Stage shifts also occur below the ground and conceptual models vary in their predictions. A belowground conceptual model proposed by Reynolds et al. (2003) suggested that positive plant-soil feedbacks dominate in early succession, thereby explaining how early successional plants may colonise relatively harsh environments. Indeed, many early succession plant species are mycorrhizal; however, some empirical studies point at negative feedback from the soil community in early stages of primary (Van der Putten et al. 1993) and secondary succession (Brown and Gange 1993; Kardol et al. 2006). Therefore, stage shifts may rather vary from negative to positive plant-soil feedback, as proposed in a conceptual plant-soil feedback succession model (Van der Putten 2003). In that case, negative plant-soil feedback promotes replacement of early successional species by plant species that are more tolerant of the root herbivores and pathogens accumulating in the root zone of their predecessors.

The conceptual model of Brown and Gange (1993) includes aboveground-belowground interactions in early stages of secondary succession. This model argues that changes in plant community composition are due to selective feeding by insect herbivores, highlighting that plantplant interactions can be altered by both aboveground and belowground interactions simultaneously. These results now have to be used to further develop the existing conceptual succession models into more predictive models taking a process- or individual-based approach (Table 1); to date, a few process-based models have been used to study belowground effects on plant competition and, consequently, on succession (Bever 2003; Bonanomi et al. 2005; Eppinga et al. 2006). Besides linking aboveground to belowground interactions, future predictive models should also account for trophic level interactions higher than herbivores or pathogens (Van der Putten et al. 2001) and effects of nutrient availability (Johnson et al. 2004), because these conditions determine the interaction strengths between plants and their enemies. This would help to understand why and at what temporal scales negative feedbacks may turn into positive feedbacks and vice versa and how this contributes to spatial variation in the composition of species and their traits in ecosystems.

Taking a reaction-diffusion modelling approach (Table 1), Fagan and Bishop (2000) argue that aboveground herbivores slow down vegetation succession, but they do not include driver effects of, for example, belowground herbivores. Such succession models could be used as a start to examine if and how positive and negative 
controls aboveground and belowground may vary depending on the abiotic properties of the environment. However, new conceptual and predictive models are needed to help exploring the patterns of trait combinations and their spatial variations that do occur in nature. Such trait-based models could be used, for example, to identify how aboveground and belowground switches from driving to slowing down the rate of succession may depend on changing status in soil fertility and soil $\mathrm{pH}$.

The synchronously operating effects of facilitation and inhibition (i.e. competition) are difficult to disentangle in empirical approaches. Predictive aboveground-belowground models may help to assess the possible outcomes of empirical studies by extrapolation in order to understand how individual or local interactions may work out in space and time. These models will enhance our insight into how progress of succession can be enhanced or slowed down by herbivores, pathogens, symbionts, decomposer organisms and predators across scales that cannot easily be dealt with by ecological experiments. Most likely, effects of facilitation and inhibition change dynamically over time and need to be considered in conjunction with other biotic and abiotic processes (Callaway and Walker 1997). For example, on a flood plain in Alaska, nitrogen-fixing alder trees (Alnus incana) facilitate nitrogen supply for spruce (Picea glauca), but shading by alder prevents spruce establishment (Walker and Chapin 1987).

Aboveground and belowground insect herbivores, pathogens and other plant enemies do not only affect plant performance and community structure, but may also interact with each other via changes in host plant quality (e.g. Moran and Whitham 1990; Masters et al. 1993) and changes in the composition of plant communities (Bezemer et al. 2006). However, ultimately, the question is whether these biotic interactions only enhance or delay future processes (Jefferies et al. 1994), or drive plant communities towards completely different states. Plant quality affects consumers of living as well as of dead plant tissues (Hättenschwiler et al. 2008), and is indirectly altered by associations with symbiotic microbes. For example, North American grasslands with endophytic fungi produced more aboveground biomass and inhibited forest development when compared to grassland plots without the fungal endophytes (Rudgers et al. 2007). These endophytes have very little biomass, but they can strongly control the state of an ecosystem and the flows of nutrients. Such microbial components receive little attention in models that quantify fluxes and flows, whereas they are important drivers of states and processes.

In fact, models should not only address the direct contribution of, for example, fungi to material fluxes, but also the way in which the fungi influence plant productivity and plant quality. The development of such models should be accompanied by empirical studies on the mechanisms underlying the interactions between the fungi and plants. Thus far, the very few predictive models that analyse nutrient cycling in relation to successional position do not take into account the biotic factors (e.g. pathogens or herbivores) that drive short-term changes in plant community composition. On the other hand, models focusing on biotic interactions should include abiotic conditions. For example, fertile soils support fast-growing, poorly defended plants that have low levels of direct defences and low levels of symbiotic associations, whereas infertile sites will have well-defended, slow-growing plants that depend strongly on symbionts for resource acquisition. Combining these approaches may provide more insight into how changing species composition along successional gradients could be a prerequisite, or a consequence of, nutrient cycling and soil development (Fig. 1).

\section{Extending the aboveground-belowground interactions concept to other areas}

Three key areas of considerable current importance are: (1) improving sustainability of agricultural crop and grassland systems; (2) understanding and combatting biological invasions; and (3) predicting the consequences of global climate change on ecosystem properties. Here, we review evidence and discuss how a more conceptual consideration based on our knowledge of succession sequences may enhance our explanatory and predictive capacity.

\section{Agro-ecosystems}

Most major food crops, such as cereals, rice and sugar beet, have characteristics of early successional, short-lived, fastgrowing plant species (Harlan 1992). Aboveground and belowground pathogens and insects, as well as viruses, root-feeding and stem nematodes are major pests in agricultural crops. The proposed trade-off between growth and defence (Herms and Mattson 1992), which might explain the susceptibility of early successional plant species, would also contribute to the susceptibility of crops for enemy attack. Breeding for high yield and good taste, as well as growing crops as single species in conditions with high fertility and ample water supply, enhance crop sensitivity to natural enemies even further.

Integrated biocontrol of the densities of pest organisms in crop systems has become of increasing importance as a tool for plant protection (Bale et al. 2008). Field margins and perennial landscape elements are key factors for maintaining populations of natural enemies of aboveground pest organisms (Tscharntke et al. 2005). However, control of belowground enemies, especially of low mobile pathogenic 


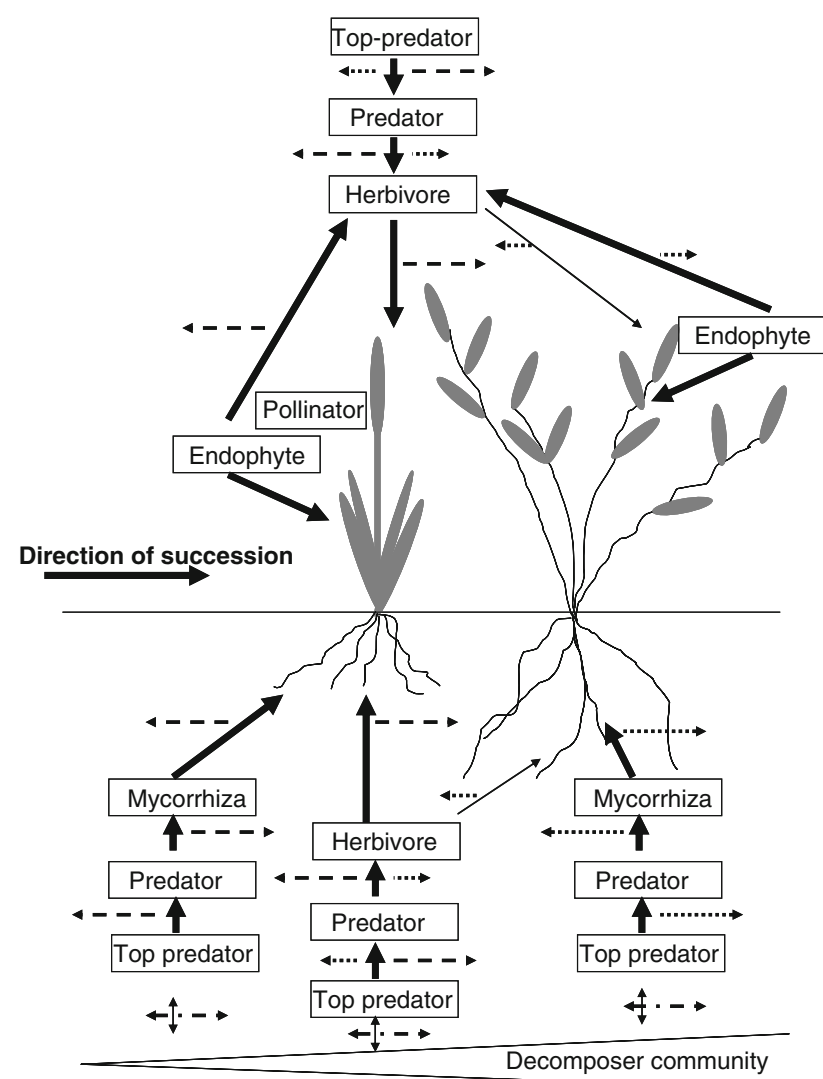

Fig. 1 Aboveground and belowground interactions between an earlier (left) and later (right) successional plant, their herbivores, symbionts (in this case, endophytes and mycorrhizal fungi), their predators and top predators. Closed lines indicate direct interactions and interrupted interactions are indirect; thick lines indicate strong interactions and thin lines weak. Long arrows indicate strong effects on the rate of succession, and short arrows weak; the direction implies driving (arrow pointing to the right), or slowing down (arrow to the left) of succession. Coarse interrupted lines relate to the early succession species; fine interrupted lines relate to the successor plant; a coarse/fine interrupted line relates to both plant species. In the case of the aboveground and belowground herbivores, we only produced an example that had stronger effects on the early than on the later successional plant species. The decomposer subsystem responds relatively slowly when compared to the herbivores and symbionts and will generally promote succession. This simplification of reality may help to explore boundary conditions where net positive effects turn into net negative effects

microbes and root-feeding nematodes, relies mainly on crop rotation and on local interactions between crop enemies and their antagonists. These soil-borne antagonists build up locally, instead of being recruited from the surrounding landscape (Kerry and Crump 1998; Weller et al. 2002). Very few crop protection studies have taken an integrated aboveground-belowground approach, and we are not aware of any conceptual or predictive models that combine these different aboveground and belowground scales. In light of the differences in spatial scales at which these aboveground and belowground crop protection measures operate, models should contain an explicit spatial dimension (Table 1).
Some studies have shown that, for example, root-feeding nematodes reduce aphid reproduction by altered bottom-up and top-down control (Sell and Kuo-Sell 1990; Bezemer et al. 2005), suggesting that highly effective control of belowground plant enemies may enhance crop sensitivity to aboveground enemies. Decomposers on the other hand stimulate aphid numbers and pathogen attack in controlled conditions (Bonkowski et al. 2001; Wurst et al. 2003), and in the field (Poveda et al. 2006). Aphids can also influence soil microbial community composition by inducing changes in plant tissue nutrient content (e.g. carbon and phosphorus), and hence microbial resource quality (Bjørnlund et al. 2006). Thus, aboveground and belowground species may control each other reciprocally, but these interactions can be easily over-ruled by changing abiotic environmental conditions (Haase et al. 2008). Predictive modelling could help to explore the different spatial and temporal dimensions of such interactions, as the abundance of nematodes and decomposer organisms depend on long-term local population dynamics influenced by crop rotation. The population dynamics of the aphids and their natural enemies, on the other hand, depend on the composition of field margins and suitable hosts in the landscape surrounding the fields, where they stay over winter and survive on alternative hosts. In such conditions, aboveground-belowground interactions require spatial and temporal dimensions that can be explored more easily by process- or individualbased models than by replicated experiments.

For decades, agronomists have examined effects of plant nutrition on susceptibility of crops for pests and pathogens. The mineral balance hypothesis states that the susceptibility of a crop depends on both absolute levels and ratios of nutrients (Phelan et al. 1996). Increased tissue nitrogen concentrations in crop plants due to N-fertilisation is positively correlated with aphid and mite numbers, although this does not necessarily lead to overall yield reduction (Altieri and Nicholls 2003). In long-term field trials, organic agriculture gave $20 \%$ less yield than conventional agriculture, whereas $97 \%$ less insecticides were used (Mäder et al. 2002). Reduced insect pressure may have been due to altered plant nutrition, but also because altered belowground decomposer communities promote aboveground aphid control by enhancing the abundance of generalist predators (Birkhofer et al. 2008).

Soil organic matter addition may also maintain predator populations in pre-crop phases by prey subsidies (Bell et al. 2008). The effectiveness of such measures may depend on, or may influence, aboveground pest control by aboveground predators that are subsidised in field margins or other surrounding landscape elements. Weighing costs and benefits of these measures alone, or in combination, could be much easier achieved through ecological-economical modelling than by experiments. In any case, models could 
be developed to identify potential key parameters that may be further studied by more targetted experiments.

In grasslands, foliar herbivores and root herbivores influence plant performance via feedback with soil organisms, mediated by altering patterns of root turnover and exudation (Hamilton and Frank 2001; Ayres et al. 2008). In intensive production grasslands, the effects of belowground herbivory become evident when renewing old stands by re-sowing (Dawson et al. 2003). In those cases, young seedlings are maximally exposed to the accumulated root herbivores and soil-borne pathogens, causing establishment problems at best or complete failures at worst. Improving soil fertility or water availability has only very limited effect on these re-sowing diseases. Aboveground, pests and pathogens play an important role in grassland management, but probably far less than in arable crops.

Modelling is widely applied in agriculture and grassland management aiming at optimising management in terms of fertiliser use, timing pesticide application, selecting crop rotations, determining effects of grazing on belowground processes and their feedback effects to productivity, as well as forecasting effects of climate change. Some models may combine nutrient management with pest management in crop systems, but there is clearly a challenge to develop models that explicitly include multiple aboveground and belowground pests and diseases, to optimise overall control in combination with manageable factors, such as soil fertility.

In spite of the relative simplicity of early successional natural systems and agricultural systems, abovegroundbelowground interactions have the tendency to produce complex feedback pathways (Altieri 1999). In order to better understand the key factors that drive these aboveground-belowground interactions, their thresholds and possible non-linear effects (Van Ruijven et al. 2005), an aboveground-belowground modelling approach applied in conjunction with empirical studies can contribute to a better understanding of these patterns and processes; for example, how to maximise crop productivity for food and biofuel production while avoiding excessive pest and pathogen outbreaks on these aggregated palatable and high quality resources.

Comparing aboveground and belowground plant-enemy interactions, primary productivity, nutrient cycling and the ability to survive adverse abiotic conditions of early successional wild plant species with crop plants could lead to new avenues for sustainable control of pests and diseases in crops and for reducing nutrient loss. Conceptual and predictive aboveground-belowground models may help to formulate and test realistic hypotheses for empirical studies. For example, aboveground-belowground modelling could be helpful in clarifying how increasing site fertility in terms of nutrient availability reduces the benefits of arbuscular mycorrhizal fungi for plant nutrition, aboveground and belowground pest and disease suppression, and crop productivity. This is crucial knowledge for future agriculture. Until recently, the lack of symbiotic mutualists in crop fields could be easily compensated for by fertilisers and pesticides. In the future, environmental concerns including climate change will lead to changes in soil use and developing marginal soils for growing of biofuel crops. Breeding for lower input farming may very well depend on mutualists for enhanced growth, drought resistance, increased nutrient uptake and pest control.

\section{Biological plant invasions}

Much of the theory on biological invasions has been developed and tested in an aboveground context. As with succession, there is a growing recognition that belowground interactions may contribute to the success of invasive species. Klironomos (2002) showed that rare native plants in general have more negative soil feedbacks than both abundant native species and exotic species. Similarly, a number of studies have shown that invaders are either less sensitive to soil biota than native species, or else exhibit more positive soil feedbacks (e.g. Reinhart et al. 2003; Callaway et al. 2004; Jordan et al. 2008). However, only a few studies have examined whether introduced species experience escape from belowground enemies as compared to their native range (Reinhart et al. 2003), although there is a plethora of papers on escape from aboveground enemies (reviewed in Liu and Stiling 2006).

To date, only a very few reports have considered both aboveground and belowground damage simultaneously on introduced species (MacKay and Kotanen 2008). Agrawal et al. (2005) did not find a systematic relationship between escape from aboveground versus belowground enemies by introduced species, and that often escape from one guild of herbivores is negated by attack from the other. Invasive exotic plant species also change the status of the soil detritus and the decomposition (Kourtev et al. 2002), but the directions and magnitudes of reported changes vary, depending on quality of the litter input, plant species and vegetation type (Belnap and Phillips 2001; Chen et al. 2007). Belowground, decomposition can also be influenced through effects of exotic plants on microclimate and soil organic matter (Mack and D'Antonio 2003).

Establishing whether impacts of aboveground or belowground interactions have positive or negative effects on introduced species may not be sufficient for determining invasiveness; the magnitude of these effects must be compared between native and introduced species in order to more fully understand the net impact of particular interactions (Levine et al. 2006). In a spatial process-based model, Eppinga et al. (2006) showed that invasive plants may 
accumulate local soil pathogens that have stronger negative effects on natives than on exotic plant species; thus, despite having negative effects on invaders, the net impact of soil pathogens favours invaders because they are even more harmful to natives. Similar impacts have been shown in barley yellow dwarf virus, which infects both native and introduced grasses, but decreases the performance of native plants much more than that of invaders (Malmstrom et al. 2005). Eppstein and Molofsky (2007) demonstrated that, when native plants undergo a strong negative feedback while introduced plants experience a strong positive feedback, four outcomes are possible: extirpation, invasion, conditional invasion or coexistence.

When conceptual or predictive models include both aboveground and belowground interactions and abiotic conditions, they may identify mechanisms of invasiveness. However, there are no aboveground-belowground models yet available to examine invasiveness. Even conceptual models put forward to explain invasiveness have often not been considered from both aboveground and belowground perspectives. For example, the evolution of increased competitive ability (EICA; Blossey and Nötzold 1995) to our knowledge has not been tested on belowground plantenemy interactions, let alone from a combined aboveground-belowground perspective.

Similarly, while many recent studies have examined effects of invasive plants on litter quality and therefore on microbial activity and biomass, and $\mathrm{N}$ mineralisation (e.g. Kourtev et al. 2002), few have included the effects of these changes on aboveground interactions. For example, exotic grasses in a California grassland double the gross nitrification rate through altered microbial communities (Hawkes et al. 2005), and nitrogen fixation by the forest invader Myrica faya in Hawaii (Vitousek et al. 1987) also increases nitrification. Such changes in plant nutrition have important consequences for aboveground interactions between plants, herbivores and their predators (e.g. Blumenthal 2006; Coley et al. 2006), however, studies that link impacts of invaders belowground to aboveground food webs are rare.

Another important plant trait that affects both aboveground and belowground processes is the novel chemistry of exotic plants (Cappuccino and Arnason 2006); phytochemicals can have strong effects on other plants (Callaway and Ridenour 2004) and also on arbuscular mycorrhizal fungi (Stinson et al. 2006; Lankau and Strauss 2007), in addition to their well-known effects on insects and pathogens. Novel chemistry may have strong decoupling impacts on the herbivores, pathogens and symbionts contributing to enhanced release and reduced resistance from natural enemies that are native in the invaded range. However, novel chemistry may also reduce functioning of the decomposer organisms or mycorrhizal fungi in the invaded range, which would negatively influence decomposition and the supply of nutrients for plant growth. There is an urgent need to examine these issues more in conjunction. For example, process- or individual-based models could be applied to identify threshold values where novel chemistry would reduce enemy exposure and still enable the benefits from symbionts and litter decomposition.

Invasive species that strongly depend on mutualists, both aboveground and belowground, may have disadvantages in invading new ranges. In addition, the differential dispersal modes and speeds of aboveground species and their belowground mutualists may also affect invasion rates. In Argentina, invasion of the surrounding habitat by Pinus radiata from established plantations is limited in large part by the dispersal of belowground mycorrhizal mutualists, which do not extend as far from plantations into the habitat as does seed rain by the trees. Mutualisms also occur aboveground (e.g. pollination), and may be limiting to invaders (Parker and Haubensak 2002). One of the standing views, however, is that mutualists are relatively non-specific (Richardson et al. 2000) and that invasive species are easily capable of acquiring new symbiotic associations in their new range, or are relatively insensitive to their lack (Jordan et al. 2008). The experimental confirmation of these views on symbiotic mutualists and exotic plant species is still in progress. For example, roughly half the studies on arbuscular mycorrhizal fungi in invasive exotic plants suggest a benefit to the invader, whereas the other half suggest no enhanced benefit. There is much scope for a combined modelling-empirical approach, which should enable a deliberate choice in the focus of the experiments on the crucial interactions and components, e.g. identified by a sensitivity analysis of the model (Saltelli et al. 2004).

\section{Climate change}

Species will likely respond to changing regional climates and a global rise in atmospheric $\mathrm{CO}_{2}$ concentrations via changes in their physiology, phenology and genetic constitution, and by changes in geographic distribution. Locally, these changes will be expressed in host quality, timing, disruption of existing interactions and the emergence of novel multitrophic level interactions. The resulting differences in growth rates of individuals and populations may be difficult to predict. In this section, we discuss how an abovegroundbelowground perspective may inform prediction of the impacts of elevated temperatures, altered precipitation and rising atmospheric $\mathrm{CO}_{2}$ concentrations on the productivity and composition of communities, and the cycling of carbon and nutrients.

Current predictions on future consequences of climate warming forecast shifting species ranges (Walther et al. 2002; Parmesan and Yohe 2003) and loss of biodiversity (Thomas et al. 2005). These shifts may not affect ecosystem 
function. For example, loss of warming-sensitive plants on primary productivity could be compensated for by warming-insensitive plant species (Cross and Harte 2007). However, suggestions that impacts on ecosystem processes under climate change may still be largely predictable from plant physiological responses (Manning et al. 2006) have not paid attention to unequal range shifts. Evidence is accumulating that range shifts may uncouple trophic interactions. Even when hosts and enemies both expand their range, they may lose their original interactions in the new range (Menendez et al. 2008). Impacts of range shifts may affect function if particular plant species can have unique effects on belowground communities (Kowalchuk et al. 2002; Porazinska et al. 2003). Indeed, novel plants may become more dominant because they are less likely to be regulated by negative soil feedbacks (Van Grunsven et al. 2007) or combinations of belowground and aboveground enemies (Engelkes et al. 2008). These interactions will affect aboveground communities through altered host plant quality (Bezemer et al. 1998), or altered aboveground multitrophic interactions. However, although the composition of soil communities affect plant assemblage composition (Bradford et al. 2002; De Deyn et al. 2003), there may be little apparent effect on ecosystem processes (Bradford et al. 2002).

It is not well understood whether the current balance of aboveground and belowground processes is likely to be maintained under climate change. For example, heterotrophic activity is generally more temperature-sensitive than photosynthesis, and while the latter is known to acclimate to both elevated $\mathrm{CO}_{2}$ and temperature (Körner 2003), there is debate as to whether soil microbial respiration will acclimate to higher temperatures (Davidson and Janssens 2006) or $\mathrm{CO}_{2}$ concentrations (Klironomos et al. 2005). One possible consequence of elevated microbial activity with temperature is enhanced nitrogen mineralisation (Rustad et al. 2001), which may increase primary productivity as well as influence plant quality for herbivores (Bezemer et al. 1998). To predict accurately whether the carbon balance of the terrestrial system will feedback positively on atmospheric $\mathrm{CO}_{2}$ concentrations and global temperature rise is a critical need for generating realistic climate change scenarios (IPCC 2007). This will also require consideration of direct effects of climate change on belowground communities and the processes that they drive, as well indirect effects mediated by changes aboveground. Food-web models (Hunt and Wall 2002), and the concepts of top-down and bottom-up regulation (Wardle et al. 2005), can generate testable hypotheses for empirical studies on this topic.

Notably, our understanding of the potential consequences of altered precipitation lags behind that of changing temperature and $\mathrm{CO}_{2}$ concentrations, but extreme events (e.g. drought or flooding) are likely to be of greater importance than changes in annual or seasonal averages (Weltzin et al. 2003). Predictive, global change research incorporating an aboveground-belowground framework is in its infancy, yet has much to offer in generating understanding how the structure and function of ecosystems will change. There is a major gap when it comes to testing hypotheses on non-synchronous temporal and spatial responses to climate change between trophic layers of plants, herbivores, carnivores and decomposer organisms and between aboveground and belowground community interactions (Engelkes et al. 2008).

Climate change may enhance photosynthesis and hence primary productivity and the flow of organic $\mathrm{C}$ to the soil community, but under $\mathrm{N}$-limited conditions this may alter the composition and substrate quality of the decomposer community, and the concomitant $\mathrm{N}$ mineralisation rates in fundamental ways (e.g. Cotrufo and Gorissen 1997). Even if we have a good understanding of response and effect traits or trait groups, threshold effects and other non-linear phenomena (Groffman et al. 2006) may still generate unanticipated changes in the system. For this reason, there is a need for empirical data on how aboveground-belowground interactions will change, and the consequent effects of these changes, under multi-factor and multi-level global change scenarios (Tylianakis et al. 2008).

What might be the most significant questions to address initially concerning aboveground-belowground interactions and global change? The first is to ask how multitrophic, aboveground-belowground interactions respond in the face of differing impacts. For example, elevated $\mathrm{CO}_{2}$ is expected to decrease foliar quality but enhance the input of labile carbon compounds to soils (Van Groenigen et al. 2006). These effects will influence plant-herbivore relationships (Bezemer et al. 1998), and cause marked changes in the structure of belowground food webs (Mikola et al. 2001). However, will this differential effect in resource quality in each domain also uncouple interactions aboveground and belowground? Similarly, as climate changes and the relative fitness of co-existing populations shifts, or there are community compositional changes, will novel aboveground-belowground interactions develop and/or will certain species be freed from 'checks and balances' as their competitors or consumers migrate at different rates? In effect, will native species become more or less abundant and will immigrating species remain rare, or become invasive? These questions are largely unanswered. Especially when considering interactive effects of global changes, such as of enhanced $\mathrm{CO}_{2}$ levels, warming and nitrogen deposition, predictive models could be helpful to explore complex parameter combinations for aboveground-belowground interactions that cannot easily be dealt with in empirical studies. 


\section{Conclusions}

Aboveground-belowground interactions have important consequences for the rate and direction of primary and secondary succession. Whether aboveground or belowground interactions may enhance or reduce the rate of succession depends on abiotic environmental conditions and the traits of the plant species that have been selected under such conditions. Many arable crops and invasive plants originate from early successional communities. Therefore, improved understanding of aboveground-belowground interactions in early succession systems might be employed to improve the sustainability of crop systems and our understanding of causes of invasiveness of exotic plant species. Responses of communities to climate change will also require information on aboveground-belowground interactions in later successional stages. However, empirical approaches to examine all possible interactions are logistically constrained. Based on our review, we propose that conceptual and predictive models should be used to provide guidance to empirical studies and that more intimate collaboration between empiricists and modellers is essential in order to enhance our capacity to predict future changes in ecosystems. Considering aboveground-belowground interactions is not only a matter of enhancing our understanding of the number of interactions involved in a particular process, such as succession or invasion. It also involves consideration of different spatial and temporal scale effects and long-lasting abiotic and biotic legacies that are characteristic of soils. Considering these peculiarities of aboveground-belowground interactions will change our perception of both long-standing and timely issues in ecology.

Acknowledgment This work was based on a workshop at Egmond, The Netherlands as part of the European Union funded network CONSIDER (Conservation of Soil Organism Diversity under Global Change), Contract no: EVK2-CT-2001-00254.

Open Access This article is distributed under the terms of the Creative Commons Attribution Noncommercial License which permits any noncommercial use, distribution, and reproduction in any medium, provided the original author(s) and source are credited.

\section{References}

Agrawal AA, Kotanen PM, Mitchell CE, Power AG, Godsoe W, Klironomos J (2005) Enemy release? An experiment with congeneric plant pairs and diverse above- and belowground enemies. Ecology 86:2979-2989

Altieri MA (1999) The ecological role of biodiversity in agroecosystems. Agric Ecosyst Environ 74:19-31

Altieri MA, Nicholls CI (2003) Soil fertility management and insect pests: harmonizing soil and plant health in agroecosystems. Soil Tillage Res 72:203-211

Augustine DJ, McNaughton SJ (1998) Ungulate effects on the functional species composition of plant communities: herbivore selectivity and plant tolerance. J Wildl Manage 62:1165-1183
Ayres E, Wall DH, Simmons BL, Field CB, Milchunas DG, Morgan JA, Roy J (2008) Belowground nematode herbivores are resistant to elevated atmospheric $\mathrm{CO} 2$ concentrations in grassland ecosystems. Soil Biol Biochem 40:978-985

Bach CE (1994) Effects of a specialist herbivore (Altica subplicata) on Salix cordata and sand dune succession. Ecol Monogr 64:423445

Bale JS, van Lenteren JC, Bigler F (2008) Biological control and sustainable food production. Philos Trans R Soc Lond B 363:761-776

Bardgett RD, Walker LR (2004) Impact of coloniser plant species on the development of decomposer microbial communities following deglaciation. Soil Biol Biochem 36:555-559

Bardgett RD, Wardle DA (2003) Herbivore-mediated linkages between aboveground and belowground communities. Ecology $84: 2258-2268$

Bardgett RD, Wardle DA, Yeates GW (1998) Linking above-ground and below-ground interactions: how plant responses to foliar herbivory influence soil organisms. Soil Biol Biochem 30:18671878

Bardgett RD, Richter A, Bol R, Garnett MH, Baumler R, Xu XL, Lopez-Capel E, Manning DAC, Hobbs PJ, Hartley IR, Wanek W (2007) Heterotrophic microbial communities use ancient carbon following glacial retreat. Biol Lett 3:487-490

Bell JR, Traugott M, Sunderland KD, Skirvin DJ, Mead A, KravarGarde L, Reynolds K, Fenlon JS, Symondson WOC (2008) Beneficial links for the control of aphids: the effects of compost applications on predators and prey. J Appl Ecol 45:1266-1273

Belnap J, Phillips SL (2001) Soil biota in an ungrazed grassland: response to annual grass (Bromus tectorum) invasion. Ecol Appl 11:1261-1275

Bennett AE, Bever JD (2007) Mycorrhizal species differentially alter plant growth and response to herbivory. Ecology 88:210-218

Bever JD (2003) Soil community feedback and the coexistence of competitors: conceptual frameworks and empirical tests. New Phytol 157:465-473

Bezemer TM, Jones TH, Knight KJ (1998) Long-term effects of elevated $\mathrm{CO} 2$ and temperature on populations of the peach potato aphid Myzus persicae and its parasitoid Aphidius matricariae. Oecologia 116:128-135

Bezemer TM, De Deyn GB, Bossinga TM, van Dam NM, Harvey JA, Van der Putten WH (2005) Soil community composition drives aboveground plant-herbivore-parasitoid interactions. Ecol Lett 8:652-661

Bezemer TM, Harvey JA, Kowalchuk GA, Korpershoek H, van der Putten WH (2006) Interplay between Senecio jacobaea and plant, soil, and aboveground insect community composition. Ecology 87:2002-2013

Birkhofer K, Bezemer TM, Bloem J, Bonkowski M, Christensen S, Dubois D, Ekelund F, Fliessbach A, Gunst L, Hedlund K, Mäder P, Mikola J, Robin C, Setälä H, Tatin-Froux F, Van der Putten WH, Scheu S (2008) Long-term organic farming fosters below and aboveground biota: implications for soil quality, biological control and productivity. Soil Biol Biochem 40:2297-2308

Bjørnlund L, Mork S, Vestergard M, Ronn R (2006) Trophic interactions between rhizosphere bacteria and bacterial feeders influenced by phosphate and aphids in barley. Biol Fertil Soils 43:1-11

Blossey B, Nötzold R (1995) Evolution of increased competitive ability in invasive nonindigenous plants-a hypothesis. J Ecol $83: 887-889$

Blumenthal DM (2006) Interactions between resource availability and enemy release in plant invasion. Ecol Lett 9:887-895

Bonanomi G, Giannino F, Mazzoleni S (2005) Negative plant-soil feedback and species coexistence. Oikos 111:311-321

Bonkowski M (2004) Protozoa and plant growth: the microbial loop in soil revisited. New Phytol 162:617-631 
Bonkowski M, Geoghegan IE, Birch ANE, Griffiths BS (2001) Effects of soil decomposer invertebrates (protozoa and earthworms) on an above-ground phytophagous insect (cereal aphid) mediated through changes in the host plant. Oikos 95:441-450

Bradford MA, Jones TH, Bardgett RD, Black HIJ, Boag B, Bonkowski M, Cook R, Eggers T, Gange AC, Grayston SJ, Kandeler E, McCaig AE, Newington JE, Prosser JI, Setälä H, Staddon PL, Tordoff GM, Tscherko D, Lawton JH (2002) Impacts of soil faunal community composition on model grassland ecosystems. Science 298:615-618

Brooker RW, Travis JMJ, Clark EJ, Dytham C (2007) Modelling species' range shifts in a changing climate: the impacts of biotic interactions, dispersal distance and the rate of climate change. J Theor Biol 245:59-65

Brown VK, Gange AC (1989) Differential effects of above-ground and below-ground insect herbivory during early plant succession. Oikos 54:67-76

Brown VK, Gange AC (1992) Secondary plant succession-how is it modified by insect herbivory? Vegetatio 101:3-13

Brown VK, Gange AC (1993) Subterranean insect herbivores in grassland ecosystems. In: Prestidge RA (ed) 6th Australasian invertebrate conference. AgResearch, Hamilton, New Zealand

Callaway RM, Ridenour WM (2004) Novel weapons: invasive success and the evolution of increased competitive ability. Front Ecol Environ 2:436-443

Callaway RM, Walker LR (1997) Competition and facilitation: a synthetic approach to interactions in plant communities. Ecology 78:1958-1965

Callaway RM, Thelen GC, Rodriguez A, Holben WE (2004) Soil biota and exotic plant invasion. Nature 427:731-733

Cappuccino N, Arnason JT (2006) Novel chemistry of invasive exotic plants. Biol Lett 2:189-193

Cates RG, Orians GH (1975) Successional status and palatability of plants to generalized herbivores. Ecology 56:410-418

Chen HL, Li B, Fang CM, Chen JK, Wu JH (2007) Exotic plant influences soil nematode communities through litter input. Soil Biol Biochem 39:1782-1793

Clay K, Holah J (1999) Fungal endophyte symbiosis and plant diversity in successional fields. Science 285:1742-1744

Coley PD, Bateman ML, Kursar TA (2006) The effects of plant quality on caterpillar growth and defense against natural enemies. Oikos 115:219-228

Connell JH, Slatyer RO (1977) Mechanisms of succession in natural communities and their role in community stability and organization. Am Nat 111:1119-1144

Cotrufo MF, Gorissen A (1997) Elevated CO2 enhances below-ground $\mathrm{C}$ allocation in three perennial grass species at different levels of N availability. New Phytol 137:421-431

Cross MS, Harte J (2007) Compensatory responses to loss of warmingsensitive plant species. Ecology 88:740-748

Davidson DW (1993) The effects of herbivory and granivory on terrestrial plant succession. Oikos 68:23-35

Davidson EA, Janssens IA (2006) Temperature sensitivity of soil carbon decomposition and feedbacks to climate change. Nature 440:165-173

Dawson LA, Grayston SJ, Murray PJ, Cook R, Gange AC, Ross JM, Pratt SM, Duff EI, Treonis A (2003) Influence of pasture management (nitrogen and lime addition and insecticide treatment) on soil organisms and pasture root system dynamics in the field. Plant Soil 255:121-130

De Deyn GB, Raaijmakers CE, Zoomer HR, Berg MP, de Ruiter PC, Verhoef HA, Bezemer TM, van der Putten WH (2003) Soil invertebrate fauna enhances grassland succession and diversity. Nature 422:711-713
De Ruiter PC, Neutel AM, Moore JC (1995) Energetics, patterns of interactions strengths, and stability in real ecosystems. Science 269: $1257-1260$

Engelkes T, Morrien E, Verhoeven KJF, Bezemer TM, Biere A, Harvey JA, McIntyre LM, Tamis WLM, van der Putten WH (2008) Successful range-expanding plants experience less aboveground and below-ground enemy impact. Nature 456:946-948

Eppinga MB, Rietkerk M, Dekker SC, De Ruiter PC, Van der Putten WH (2006) Accumulation of local pathogens: a new hypothesis to explain exotic plant invasions. Oikos 114:168-176

Eppstein MJ, Molofsky J (2007) Invasiveness in plant communities with feedbacks. Ecol Lett 10:253-263

Fagan WF, Bishop JG (2000) Trophic interactions during primary succession: herbivores slow a plant reinvasion at Mount St. Helens. Am Nat 155:238-251

Gange AC, Brown VK (2002) Actions and interactions of soil invertebrates and arbuscular mycorrhizal fungi affecting the structure of plant communities. In: van der Heijden MGA, Sanders IR (eds) Mycorrhizal ecology. Springer, Berlin

Grime JP (2001) Plant strategies, vegetation processes, and ecosystem properties. Wiley, New York

Groffman PM, Altabet MA, Bohlke JK, Butterbach-Bahl K, David MB, Firestone MK, Giblin AE, Kana TM, Nielsen LP, Voytek MA (2006) Methods for measuring denitrification: diverse approaches to a difficult problem. Ecol Appl 16:2091-2122

Haase J, Brandl R, Scheu S, Schadler M (2008) Above- and belowground interactions are mediated by nutrient availability. Ecology 89:3072-3081

Hamilton EW, Frank DA (2001) Can plants stimulate soil microbes and their own nutrient supply? Evidence from a grazing tolerant grass. Ecology 82:2397-2402

Harlan JR (1992) Crops \& Man, 2nd edn. American Society of Agronomy, Crop Science Society of America, Madison

Hart MM, Reader RJ, Klironomos JN (2001) Life-history strategies of arbuscular mycorrhizal fungi in relation to their successional dynamics. Mycologia 93:1186-1194

Hättenschwiler S, Aeschlimann B, Couteaux MM, Roy J, Bonal D (2008) High variation in foliage and leaf litter chemistry among 45 tree species of a neotropical rainforest community. New Phytol 179:165-175

Hawkes CV, Wren IF, Herman DJ, Firestone MK (2005) Plant invasion alters nitrogen cycling by modifying the soil nitrifying community. Ecol Lett 8:976-985

Herms DA, Mattson WJ (1992) The dilemma of plants-to grow or defend. Q Rev Biol 67:283-335

Hines J, Megonigal JP, Denno RF (2006) Nutrient subsidies to belowground microbes impact aboveground food web interactions. Ecology 87:1542-1555

Holmgren M, Scheffer M, Huston MA (1997) The interplay of facilitation and competition in plant communities. Ecology 78:1966-1975

Hunt HW, Wall DH (2002) Modelling the effects of loss of soil biodiversity on ecosystem function. Glob Chang Biol 8:33-50

Huston MA, DeAngelis DL (1994) Competition and coexistence-the effects of resource transport and supply rates. Am Nat 144:954-977

IPCC (2007) Climate change 2007: the physical science basis. Contribution of Working Group 1 to the Fourth Assessment Report of the Intergovernmental Panel on Climate Change. In: Solomon S et al (eds) Cambridge University Press, Cambridge

Jefferies RL, Klein DR, Shaver GR (1994) Vertebrate herbivores and northern plant communities-reciprocal influences and responses. Oikos 71:193-206

Johnson NC, Zak DR, Tilman D, Pfleger FL (1991) Dynamics of vesicular-arbuscular mycorrhizae during old field succession. Oecologia 86:349-358 
Johnson SN, Read DB, Gregory PJ (2004) Tracking larval insect movement within soil using high resolution X-ray microtomography. Ecol Entomol 29:117-122

Jordan NR, Larson DL, Huerd SC (2008) Soil modification by invasive plants: effects on native and invasive species of mixed-grass prairies. Biol Invasions 10:177-190

Kardol P, Bezemer TM, van der Putten WH (2006) Temporal variation in plant-soil feedback controls succession. Ecol Lett 9:1080-1088

Kerry BR, Crump DH (1998) The dynamics of the decline of the cereal cyst nematode, Heterodera avenae, in four soils under intensive cereal production. Fundam Appl Nematol 21:617-625

Klironomos JN (2002) Feedback with soil biota contributes to plant rarity and invasiveness in communities. Nature 417:67-70

Klironomos JN, Allen MF, Rillig MC, Piotrowski J, Makvandi-Nejad S, Wolfe BE, Powell JR (2005) Abrupt rise in atmospheric CO2 overestimates community response in a model plant-soil system. Nature 433:621-624

Körner C (2003) Slow in, rapid out-carbon flux studies and Kyoto targets. Science 300:1242-1243

Kourtev PS, Ehrenfeld JG, Haggblom M (2002) Exotic plant species alter the microbial community structure and function in the soil. Ecology 83:3152-3166

Kowalchuk GA, Buma DS, de Boer W, Klinkhamer PGL, van Veen JA (2002) Effects of above-ground plant species composition and diversity on the diversity of soil-borne microorganisms. Antonie Van Leeuwenhoek Int J Gen Mol Microbiol 81:509-520

Lankau RA, Strauss SY (2007) Mutual feedbacks maintain both genetic and species diversity in a plant community. Science 317:15611563

Levine JM, Pachepsky E, Kendall BE, Yelenik SG, Lambers JH (2006) Plant-soil feedbacks and invasive spread. Ecol Lett 9:1005-1014

Liu H, Stiling P (2006) Testing the enemy release hypothesis: a review and meta-analysis. Biol Invasions 8:1535-1545

Loreau M (1998) Biodiversity and ecosystem functioning: a mechanistic model. Proc Natl Acad Sci USA 95:5632-5636

Mack MC, D'Antonio CM (2003) Exotic grasses alter controls over soil nitrogen dynamics in a Hawaiian woodland. Ecol Appl 13:154-166

MacKay J, Kotanen PM (2008) Local escape of an invasive plant, common ragweed (Ambrosia artemisiifolia L.), from above-ground and below-ground enemies in its native area. J Ecol 96:1152-1161

Mäder P, Fliessbach A, Dubois D, Gunst L, Fried P, Niggli U (2002) Soil fertility and biodiversity in organic farming. Science 296:1694-1697

Malmstrom CM, McCullough AJ, Johnson HA, Newton LA, Borer ET (2005) Invasive annual grasses indirectly increase virus incidence in California native perennial bunchgrasses. Oecologia 145:153164

Manning P, Newington JE, Robson HR, Saunders M, Eggers T, Bradford MA, Bardgett RD, Bonkowski M, Ellis RJ, Gange AC, Grayston SJ, Kandeler E, Marhan S, Reid E, Tscherko D, Godfray HCJ, Rees M (2006) Decoupling the direct and indirect effects of nitrogen deposition on ecosystem function. Ecol Lett 9:10151024

Masters GJ, Brown VK (1997) Host-mediated interactions between spatially separated herbivores: effects on community structure. In: Gange AC, Brown VK (eds) Multitrophic interactions in terrestrial ecosystems. Proceedings of the 36th symposium of the British Ecological Society, Blackwell, Royal Holloway College, University of London, pp 217-238

Masters GJ, Brown VK, Gange AC (1993) Plant mediated interactions between aboveground and belowground insect herbivores. Oikos 66:148-151

Menendez R, Gonzalez-Megias A, Lewis OT, Shaw MR, Thomas CD (2008) Escape from natural enemies during climate-driven range expansion: a case study. Ecol Entomol 33:413-421
Meyer KM, Vos M, Mooij WM, Hol WHG, Termorshuizen A, Vet LEM, van der Putten WH (2009) Quantifying the impact of above- and belowground higher trophic levels on plant and herbivore performance by modeling. Oikos. doi:10.1111/j.1600-0706. 2009.17220.x

Mikola J, Yeates GW, Barker GM, Wardle DA, Bonner KI (2001) Effects of defoliation intensity on soil food-web properties in an experimental grassland community. Oikos 92:333-343

Moore JC, McCann K, Setälä H, De Ruiter PC (2003) Top-down is bottom-up: does predation in the rhizosphere regulate aboveground dynamics? Ecology 84:846-857

Moore JC, Berlow EL, Coleman DC, de Ruiter PC, Dong Q, Hastings A, Johnson NC, McCann KS, Melville K, Morin PJ, Nadelhoffer K, Rosemond AD, Post DM, Sabo JL, Scow KM, Vanni MJ, Wall DH (2004) Detritus, trophic dynamics and biodiversity. Ecol Lett 7:584-600

Moran NA, Whitham TG (1990) Interspecific competition between root-feeding and leaf-falling aphids mediated by host-plant resistance. Ecology 71:1050-1058

Neutel AM, Heesterbeek JAP, van de Koppel J, Hoenderboom G, Vos A, Kaldeway C, Berendse F, de Ruiter PC (2007) Reconciling complexity with stability in naturally assembling food webs. Nature 449:599 U511

Olff H, Pegtel DM, Van Groenendael JM, Bakker JP (1994) Germination strategies during grassland succession. J Ecol 82:69-77

Parker IM, Haubensak KA (2002) Comparative pollinator limitation of two non-native shrubs: do mutualisms influence invasions? Oecologia 130:250-258

Parmesan C, Yohe G (2003) A globally coherent fingerprint of climate change impacts across natural systems. Nature 421:37-42

Pastor J, Dewey B, Naiman RJ, McInnes PF, Cohen Y (1993) Moose browsing and soil fertility in the boreal forests of Isle Royale National Park. Ecology 74:467-480

Phelan PL, Norris KH, Mason JF (1996) Soil-management history and host preference by Ostrinia nubilalis: evidence for plant mineral balance mediating insect-plant interactions. Environ Entomol 25:1329-1336

Porazinska DL, Bardgett RD, Blaauw MB, Hunt HW, Parsons AN, Seastedt TR, Wall DH (2003) Relationships at the abovegroundbelowground interface: plants, soil biota, and soil processes. Ecol Monogr 73:377-395

Poveda K, Steffan-Dewenter I, Scheu S, Tscharntke T (2006) Belowground effects of organic and conventional farming on aboveground plant-herbivore and plant-pathogen interactions. Agric Ecosyst Environ 113:162-167

Reinhart KO, Packer A, Van der Putten WH, Clay K (2003) Plant-soil biota interactions and spatial distribution of black cherry in its native and invasive ranges. Ecol Lett 6:1046-1050

Reynolds HL, Packer A, Bever JD, Clay K (2003) Grassroots ecology: plant-microbe-soil interactions as drivers of plant community structure and dynamics. Ecology 84:2281-2291

Richardson DM, Allsopp N, D'Antonio CM, Milton SJ, Rejmanek M (2000) Plant invasions - the role of mutualisms. Biol Rev 75:6593

Rietkerk M, Van de Koppel J (1997) Alternate stable states and threshold effects in semi-arid grazing systems. Oikos 79:69-76

Ritchie ME, Tilman D, Knops JMH (1998) Herbivore effects on plant and nitrogen dynamics in oak savanna. Ecology 79:165-177

Rudgers JA, Holah J, Orr SP, Clay K (2007) Forest succession suppressed by an introduced plant-fungal symbiosis. Ecology $88: 18-25$

Rustad LE, Campbell JL, Marion GM, Norby RJ, Mitchell MJ, Hartley AE, Cornelissen JHC, Gurevitch J (2001) A meta-analysis of the response of soil respiration, net nitrogen mineralization, and aboveground plant growth to experimental ecosystem warming. Oecologia 126:543-562 
Saltelli A, Chan K, Scott EM (2004) Sensitivity analysis. Wiley, Chichester

Schädler M, Jung G, Brandl R, Auge H (2004) Secondary succession is influenced by belowground insect herbivory on a productive site. Oecologia 138:242-252

Scheu S (2001) Plants and generalist predators as links between the below-ground and above-ground system. Basic Appl Ecol 2:3-13

Schmidt SK, Reed SC, Nemergut DR, Grandy AS, Cleveland CC, Weintraub MN, Hill AW, Costello EK, Meyer AF, Neff JC, Martin AM (2008) The earliest stages of ecosystem succession in high-elevation (5000 metres above sea level), recently deglaciated soils. Proc R Soc Lond B 275:2793-2802

Schröter D, Brussaard L, De Deyn G, Poveda K, Brown VK, Berg MP, Wardle DA, Moore J, Wall DH (2004) Trophic interactions in a changing world: modelling aboveground-belowground interactions. Basic Appl Ecol 5:515-528

Sell P, Kuo-Sell HL (1990) Influence of infestation of oats by root-knot nematodes (Meloidogyne sp.) on the performance of the cereal aphid, Metopolophium dirhodum (Walk) (Hom Aphididae). J Appl Entomol 109:37-43

Stinson KA, Campbell SA, Powell JR, Wolfe BE, Callaway RM, Thelen GC, Hallett SG, Prati D, Klironomos JN (2006) Invasive plant suppresses the growth of native tree seedlings by disrupting belowground mutualisms. PLoS Biol 4:727-731

Thomas DSG, Knight M, Wiggs GFS (2005) Remobilization of southern African desert dune systems by twenty-first century global warming. Nature 435:1218-1221

Tilman D (1988) Plant strategies and the dynamics and structure of platn communities. Princeton University Press, Princeton

Tscharntke T, Klein AM, Kruess A, Steffan-Dewenter I, Thies C (2005) Landscape perspectives on agricultural intensification and biodiversity-ecosystem service management. Ecol Lett 8:857874

Tylianakis JM, Didham RK, Bascompte J, Wardle DA (2008) Global change and species interactions in terrestrial ecosystems. Ecol Lett 11:1351-1363

Van der Putten WH (2003) Plant defense belowground and spatiotemporal processes in natural vegetation. Ecology 84:2269-2280

Van der Putten WH, Van Dijk C, Peters BAM (1993) Plant-specific soil-borne diseases contribute to succession in foredune vegetation. Nature 362:53-56

Van der Putten WH, Vet LEM, Harvey JA, Wäckers FL (2001) Linking above- and belowground multitrophic interactions of plants, herbivores, pathogens, and their antagonists. Trends Ecol Evol $16: 547-554$
Van der Wal R, Egas M, Van der Veen A, Bakker J (2000) Effects of resource competition and herbivory on plant performance along a natural productivity gradient. J Ecol 88:317-330

Van Groenigen KJ, Six J, Hungate BA, De Graaff MA, Van Breemen N, Van Kessel C (2006) Element interactions limit soil carbon storage. Proc Natl Acad Sci USA 103:6571-6574

Van Grunsven RHA, Van der Putten WH, Bezemer TM, Tamis WLM, Berendse F, Veenendaal EM (2007) Reduced plant-soil feedback of plant species expanding their range as compared to natives. J Ecol 95:1050-1057

Van Ruijven J, De Deyn GB, Raaijmakers CE, Berendse F, van der Putten WH (2005) Interactions between spatially separated herbivores indirectly alter plant diversity. Ecol Lett 8:30-37

Veblen KE (2008) Season- and herbivore-dependent competition and facilitation in a semiarid savanna. Ecology 89:1532-1540

Vitousek PM, Walker LR, Whiteaker LD, Muellerdombois D, Matson PA (1987) Biological invasion by Myrica faya alters ecosystem development in Hawaii. Science 238:802-804

Walker LR, Chapin FS (1987) Interactions among processes controlling successional changes. Oikos 50:131-135

Walker LR, del Moral R (2003) Primary succession and ecosystem rehabilitation. Cambridge University Press, Cambridge

Walther GR, Post E, Convey P, Menzel A, Parmesan C, Beebee TJC, Fromentin JM, Hoegh-Guldberg O, Bairlein F (2002) Ecological responses to recent climate change. Nature 416:389-395

Wardle DA (2002) Communities and ecosystems: linking the aboveground and the belowground components. Princeton University Press, Princeton

Wardle DA, Walker LR, Bardgett RD (2004) Ecosystem properties and forest decline in contrasting long-term chronosequences. Science 305:509-513

Wardle DA, Williamson WM, Yeates GW, Bonner KI (2005) Trickledown effects of aboveground trophic cascades on the soil food web. Oikos 111:348-358

Weller DM, Raaijmakers JM, Gardener BBM, Thomashow LS (2002) Microbial populations responsible for specific soil suppressiveness to plant pathogens. Annu Rev Phytopathol 40:309-348

Weltzin JF, Loik ME, Schwinning S, Williams DG, Fay PA, Haddad BM, Harte J, Huxman TE, Knapp AK, Lin GH, Pockman WT, Shaw MR, Small EE, Smith MD, Smith SD, Tissue DT, Zak JC (2003) Assessing the response of terrestrial ecosystems to potential changes in precipitation. Bioscience 53:941-952

Wurst S, Langel R, Reineking A, Bonkowski M, Scheu S (2003) Effects of earthworms and organic litter distribution on plant performance and aphid reproduction. Oecologia 137:90-96 